\title{
PENGARUH PENAMBAHAN KITOSAN TERHADAP KARAKTERISTIK KERUPUK GENDAR
}

\author{
Beti Cahyaning Astuti \\ FMIPA, Universitas Terbuka \\ e-mail: beti@ut.ac.id
}

\begin{abstract}
Rice cracker is a local crispy snack made of cooked rice as the main component and traditionally bleng as an additive that function as a thickening agent. However, bleng contains borax, an element which is harmful for human health. This research was important to substitute the role of bleng as a thickening agent. The objective of this research was to evaluate the effect of chitosan addition on physical, chemical, and organoleptic characteristics of fried rice cracker. Based on the physical analysis of unfolding rice cracker was $28,970-45,487 \%$ and oil absorption was $24,406-40,925 \%$. Based on the chemical analysis it was found that the content of waterrice cracker $(1,275-1,986 \%)$; ash $(0,311$ 1,775\%); fat (31,511-33,508\%); proteins (4,185-6,250\%); carbohydrates (58,546-59,744\%). The organoleptic test on the color and taste of the fried rice cracker gave the significant results on all treatments.

Keywords: bleng, chitosan, rice cracker
\end{abstract}

\begin{abstract}
ABSTRAK
Kerupuk gendar merupakan produk makanan ringan yang terbuat dari bahan dasar beras dengan bahan tambahan bleng yang berfungsi sebagai agen pengenyal. Namun, bleng mengandung boraks, unsur yang berbahaya bagi kesehatan manusia. Penelitian ini bertujuan untuk mengevaluasi pengaruh penambahan kitosan sebagai pengganti bleng pada karakteristik fisik, kimia, dan organoleptik kerupuk gendar. Berdasarkan analisis fisik kerupuk gendar goreng diketahui daya kembang sebesar $28,970-45,487 \%$ dan daya serap minyak sebesar $24,406-40,925 \%$. Berdasarkan analisis kimia kerupuk gendar goreng diketahui kadar air (1,275-1,986\%); kadar abu (0,311-1,775\%); lemak (31,511-33,508\%); protein (4,185-6,250\%); dan karbohidrat (58,546-59,744\%). Hasil analisis sensori kerupuk gendar goreng berpengaruh nyata terhadap warna dan rasa.
\end{abstract}

Kata kunci: bleng, kerupuk gendar, kitosan

Kerupuk gendar merupakan produk pangan kering dari proses penggorengan, berbentuk lempengan tipis, bulat atau persegi panjang, yang terbuat dari bahan dasar beras dengan berbagai cita rasa tergantung bumbu-bumbu yang ditambahkan. Penggunaan bahan tambahan pangan dalam industri pangan semakin luas dan meningkat. Banyak masyarakat, karena pendidikan dan pengetahuannya yang kurang, menggunakan bahan tambahan pangan yang tidak diijinkan oleh Departemen Kesehatan RI atau yang dapat mengganggu kesehatan. Misalnya dalam proses pembuatan kerupuk gendar, masyarakat menggunakan bahan tambahan pangan yang berupa bleng 
padatan. Bahan tambahan tersebut digunakan untuk memperbaiki tekstur (kenyal) adonan gendar, sehingga mudah pengirisannya, awet, setelah digoreng mengembang, empuk, teksturnya bagus dan renyah (Setyowati, 2010).

Menurut Mahdar (1990), bleng padatan mengandung boraks $12 \%$, garam dapur $60 \%$, natrium karbonat $28 \%$, dan mineral $0,4 \%$ sebagai besi dan kalsium. Oleh karena bleng padatan mengandung boraks, maka dapat mengganggu kesehatan apabila dikonsumsi. Oleh karena itu dilakukan penelitian penggunaan bahan tambahan pangan yang lain sebagai pengganti bleng padatan pada pembuatan kerupuk gendar, yaitu kitosan yang tidak mengganggu kesehatan.

Pada penelitian ini dilakukan pembuatan kerupuk gendar dengan penambahan kitosan. Kitosan dipilih berdasarkan pertimbangan bahwa ketersediaan limbah udang cukup banyak dan mudah diperoleh. Udang merupakan salah satu komoditas hasil perikanan di Indonesia yang diperdagangkan dalam pasar lokal dan ekspor. Melalui pendekatan teknologi yang tepat, potensi limbah ini dapat diolah lebih lanjut menjadi kitin dan kitosan.

Penelitian ini bertujuan untuk mengetahui karakteristik kerupuk gendar yang dihasilkan dengan penambahan kitosan. Produk yang diharapkan adalah kerupuk gendar yang mempunyai karakteristik hampir sama dengan kerupuk gendar dengan penambahan bleng yang disukai oleh panelis dan aman bagi kesehatan.

\section{METODE}

Penelitian ini dilakukan di Laboratorium Universitas Setia Budi, Surakarta. Penelitian dimulai dengan pembuatan kerupuk gendar kemudian dianalisis karakteristik fisik, kimia, dan sensori. Pembuatan kerupuk gendar dilakukan dengan cara beras dicuci bersih dan dimasak menjadi nasi. Nasi ditimbang sebanyak 400 gram, kemudian dicampur dengan bahan tambahan pangan sebagai perlakuan variasi bleng 1,0\%; kitosan $0,5 \% ; 1,0 \%$; dan $1,5 \%(\mathrm{~b} / \mathrm{b})$ dengan pelarut air untuk bleng dan $2 \%$ (b/v) asam laktat untuk kitosan sebanyak $20 \mathrm{ml}$. Selanjutnya campuran dikukus selama 30 menit, kemudian digiling dengan gilingan daging 1 kali. Hasil gilingan ditampung dan dipadatkan pada loyang, dibiarkan dingin. Selanjutnya adonan diiris dengan pisau setebal $1,5 \mathrm{~mm}$, dikeringkan selama kurang lebih 2 hari dengan sinar matahari sehingga didapatkan kerupuk gendar mentah.

Kerupuk gendar mentah digoreng dengan suhu $210^{\circ} \mathrm{C}$ selama 10 detik (Setyowati, 2010). Kemudian kerupuk gendar goreng dianalisis karakteristik fisik, kimia, dan sensori. Analisis karakteristik fisik meliputi daya kembang dan daya serap minyak. Daya kembang kerupuk diukur dari persentase perbandingan antara selisih keliling kerupuk mentah dan keliling kerupuk goreng dengan keliling kerupuk mentah. Daya serap minyak kerupuk diukur dengan membandingkan berat kerupuk mentah dan berat kerupuk setelah digoreng. Analisiskimia meliputi kadar air, kadar abu, lemak, protein, dan karbohidrat dengan metode AOAC 1990 (Anonim, 1990). Analisis sensori meliputi warna, kerenyahan, dan rasa dengan menggunakan uji kesukaan.

Pelaksanaan penelitian dengan menggunakan Rancangan Acak Lengkap (RAL) dengan ulangan sebanyak 2 kali dan dianalisis menggunakan Statistical Product and Service Solution (SPSS) versi 17 dengan metode analisis variance (ANOVA) pada tingkat kepercayaan 95\%, jika terdapat perbedaan yang nyata dilanjutkan dengan uji Duncan Multiple Range Test (DMRT).

\section{HASIL DAN PEMBAHASAN Analisis Fisik}

Sifat fisik kerupuk gendar yang dianalisis adalah daya kembang dan daya serap minyak. 


\section{Daya Kembang}

Daya kembang kerupuk gendar goreng sangat dipengaruhi jenis bahan tambahan pangan yang digunakan. Hasil analisis daya kembang kerupuk gendar dapat dilihat pada Tabel 1. Daya kembang perlakuan dengan bleng lebih besar dibandingkan dengan penambahan kitosan yaitu sebesar 45,487\%. Pengembangan makanan yang digoreng dapat dijelaskan dengan menggunakan konsep peningkatan secara cepat dalam volume molekul air selama penguapan (Rossell, 2001). Penambahan kitosan meningkatkan kandungan protein dalam kerupuk gendar (Tabel 3). Menurut Yohii dan Arisaka (1994), protein mengurangi pengembangan dari amilopektin di pati beras selama penggorengan dan menyebabkan pengurangan rasio pengembangan. Selain itu, penambahan protein dalam pati akan mengurangi kelarutan pati setelah gelatinisasi (Zhang dan Hamaker, 2003).

Daya kembang perlakuan kitosan 1,0\% yaitu sebesar 35,973\%, lebih tinggi dibandingkan dengan daya kembang perlakuan kitosan 0,5\% yaitu sebesar 31,013\%. Faktor lain yang dapat berpengaruh terhadap daya kembang adalah pengadukan di dalam pembuatan kerupuk. Pencampuran adonan yang tidak homogen menyebabkan penurunan gelatinisasi pati sehingga daya kembang akan menurun dan menghasilkan karakteristik pengembangan yang jelek.

\section{Daya Serap Minyak}

Daya serap minyak adalah salah satu parameter yang penting mengendalikan kualitas, kerenyahan, dan warna kerupuk gendar goreng.

Tabel 1. Hasil Analisis \% Daya Kembang Kerupuk Gendar Goreng.

\begin{tabular}{lc}
\hline Perlakuan & $\%$ Daya Kembang \\
\hline Bleng $1,0 \%$ & $45,487 \pm 0,447 \mathrm{a}$ \\
Kitosan $0,5 \%$ & $31,013 \pm 0,732 \mathrm{c}$ \\
Kitosan $1,0 \%$ & $35,973 \pm 0,015 \mathrm{~b}$ \\
Kitosan $1,5 \%$ & $28,970 \pm 0,401 \mathrm{~d}$ \\
\hline
\end{tabular}

Keterangan: Angka yang diikuti huruf yang sama tidak berbeda nyata pada taraf uji $5 \%$

Tabel 2. Hasil Analisis \% Daya Serap Minyak Kerupuk Gendar Goreng.

\begin{tabular}{lc}
\hline Perlakuan & \% Daya Serap Minyak \\
\hline Bleng 1,0\% & $40,925 \pm 0,281 \mathrm{a}$ \\
Kitosan 0,5\% & $34,362 \pm 0,619 \mathrm{c}$ \\
Kitosan 1,0\% & $30,210 \pm 0,376 \mathrm{~b}$ \\
Kitosan 1,5\% & $24,406 \pm 0,105 \mathrm{~d}$ \\
\hline
\end{tabular}

Keterangan:Angka yang diikuti huruf yang sama tidak berbeda nyata pada taraf uji $5 \%$

Hasilan analisis daya serap minyak kerupuk gendar sebesar 24,406-40,925\% (Tabel 2). Penambahan kitosan akan menurunkan daya serap minyak kerupuk gendar. Daya serap minyak kerupuk merupakan kemampuan kerupuk di dalam menyerap minyak setelah digoreng. Daya serap minyak yang tinggi menunjukkan terjadinya bagian yang matang dari kerupuk secara menyeluruh sehingga bagian tersebut menyerap banyak minyak. Jumlah minyak yang terkandung di dalam permukaan kerupuk menyebabkan kondisi kerupuk menjadi lebih berat dan kerupuk menjadi matang. Hasilnya mungkin dijelaskan oleh pembentukan kerak, yang bertindak sebagai penghalang untuk mengurangi penyerapan minyak. Selain itu, pembentukan kerak mungkin mencegah air di dalam 
melarikan diri ke luar dan akibatnya mencegah penyerapan minyak lebih lanjut dengan kerupuk nasi (Rossell, 2001).

Daya serap minyak kerupuk gendar goreng dapat dijelaskan dengan mekanisme kondensasi dan kapiler. Selama proses penggorengan, kadar air kerupuk gendar berubah menjadi uap karena panas. Uap menguap dari kerupuk gendar dan menciptakan tekanan berlebihan dalam pori-pori. Akibatnya, minyak goreng tidak mampu menembus ke pori-pori selama menggoreng. Ketika kerupuk gendar goreng telah diangkat dari minyak goreng, suhu pori di dalam kerupuk gendar turun dan uap di kerak kental. Tekanan berlebihan berubah menjadi tekanan di bawah, sedangkan minyak berpegang pada permukaan kerupuk gendar. Oleh karena itu, minyak didorong ke dalam pori-pori (Mellema, 2003).

\section{Analisis Kimia}

Hasil analisis proksimat untuk kadar air, kadar abu, lemak, protein,dan karbohidrat dapat dilihat pada Tabel 3. Perlakuan bleng 1,0\%; kitosan 0,5\%; kitosan1,0\%; dan kitosan 1,5\% (b/b) tidak mempengaruhi kandungan karbohidrat pada kerupuk gendar goreng.

Tabel 3. Hasil Analisis Kadar Air, Kadar Abu, Lemak, Protein, dan Karbohidrat Kerupuk Gendar Goreng.

\begin{tabular}{lrrrr}
\hline \multirow{2}{*}{ Analisis } & \multicolumn{4}{c}{ Perlakuan } \\
\cline { 2 - 5 } \multicolumn{1}{c}{ Bleng 1,0\% } & \multicolumn{1}{c}{ Kitosan 0,5\% } & \multicolumn{1}{c}{ Kitosan 1,0\% } & \multicolumn{1}{c}{ Kitosan 1,5\% } \\
\hline Kadar Air (\%) & $1,986 \pm 0,040^{\mathrm{d}}$ & $1,698 \pm 0,018^{\mathrm{c}}$ & $1,485 \pm 0,035^{\mathrm{b}}$ & $1,275 \pm 0,064^{\mathrm{a}}$ \\
Kadar Abu (\%) & $1,775 \pm 0,035^{\mathrm{a}}$ & $0,718 \pm 0,005^{\mathrm{b}}$ & $0,311 \pm 0,006^{\mathrm{c}}$ & $0,317 \pm 0,004^{\mathrm{c}}$ \\
Lemak (\%) & $33,508 \pm 0,017^{\mathrm{a}}$ & $33,114 \pm 0,014^{\mathrm{b}}$ & $32,730 \pm 0,057^{\mathrm{c}}$ & $31,511 \pm 0,0^{\mathrm{d}} \mathrm{d}$ \\
Protein (\%) & $4,185 \pm 0,064^{\mathrm{a}}$ & $4,965 \pm 0,007^{\mathrm{b}}$ & $5,925 \pm 0,050^{\mathrm{c}}$ & $6,250 \pm 0,057^{\mathrm{d}}$ \\
Karbohidrat (\%) & $58,546 \pm 0,051^{\mathrm{a}}$ & $59,717 \pm 0,031^{\mathrm{a}}$ & $59,544 \pm 0,064^{\mathrm{a}}$ & $59,744 \pm 0,251^{\mathrm{a}}$ \\
\hline
\end{tabular}

Keterangan: Angka yang diikuti huruf yang sama pada kolom yang sama tidak berbeda nyata pada taraf uji $5 \%$

Tabel 4. Hasil Analisis Sensori Kerupuk Gendar Goreng.

\begin{tabular}{lccc}
\hline \multirow{2}{*}{ Perlakuan } & \multicolumn{3}{c}{ Analisis } \\
\cline { 2 - 4 } & Warna & Kerenyahan & Rasa \\
\hline Bleng $1,0 \%$ & $4,97^{\mathrm{a}}$ & $4,90^{\mathrm{a}}$ & $4,63^{\mathrm{a}}$ \\
Kitosan $0,5 \%$ & $4,90^{\mathrm{a}}$ & $5,00^{\mathrm{a}}$ & $4,10^{\mathrm{b}}$ \\
Kitosan $1,0 \%$ & $4,90^{\mathrm{a}}$ & $4,93^{\mathrm{a}}$ & $4,07^{\mathrm{c}}$ \\
Kitosan $1,5 \%$ & $3,23^{\mathrm{b}}$ & $4,87^{\mathrm{a}}$ & $2,27^{\mathrm{d}}$ \\
\hline
\end{tabular}

Keterangan: Angka yang diikuti huruf yang sama pada kolom yang sama tidak berbeda nyata pada taraf uji $5 \%$

Komposisi proksimat dalam makanan merupakan indikator kandungan nilai nutrisi dalam makanan. Semakin tinggi kadar protein, karbohidrat, serat kasar, abu, dan vitamin, semakin tinggi pula nilai gizi makanan tersebut. Hasil analisis data sifat kimia kadar air dan protein kerupuk gendar goreng berbeda nyata antara kerupuk gendar berbahan bleng dengan berbahan kitosan (Tabel 3). Hasil analisis data kadar air kerupuk gendar goreng dengan penambahan bleng 1,0\% lebih tinggi dibandingkan dengan kadar air kerupuk gendar goreng dengan penambahan kitosan. Hal ini dapat dikaitkan dengan kandungan protein yang terdapat dalam kerupuk gendar goreng. Hasil analisis kerupuk gendar goreng berpengaruh nyata terhadap protein. Penambahan kitosan meningkatkan 
kandungan protein kerupuk gendar goreng. Kitosan adalah bahan makanan yang tinggi kandungan protein, sehingga mengurangi water holding capacity dari campuran protein-pati selama pemanasan (Skipnese, at al., 2008). Hal ini terlihat dengan penambahan kitosan menurunkan kadar air kerupuk gendar goreng.

Kandungan lemak yang tinggi karena kerupuk gendar menyerap minyak selama penggorengan. Hasil analisis lemak kerupuk gendar goreng dengan penambahan bleng 1,0\% lebih tinggi dibandingkan dengan kadar air kerupuk gendar goreng dengan penambahan kitosan. Hasil analisis lemak berhubungan dengan kemampuan daya serap minyak kerupuk gendar menurun dengan penambahan kitosan (Tabel 2).

Hasil analisis sensori kerupuk gendar goreng. Berdasarkan hasil analisis perlakuan penambahan bleng dan kitosan menunjukkan tidak berpengaruh nyata terhadap kerenyahan kerupuk gendar goreng secara sensori (Tabel 4). Penambahan kitosan menyebabkan warna kerupuk gendar goreng semakin gelap. Penambahan kitosan akan meningkatkan kandungan asam amino dalam kerupuk gendar. Dengan demikian, reaksi Maillard pencoklatan mudah terjadi dengan peningkatan kitosan yang mengakibatkan warna kerupuk goreng lebih coklat. Reaksi Maillard pencoklatan merupakan reaksi non-enzimatik antara asam amino dan gula reduksi, adalah pembentukan warna dasar reaksi (Baik dan Mittal, 2003; Moyano, Rioseco, Gonzalez, 2002). Secara sensori, panelis kurang suka dengan penambahan kitosan $1,5 \%$.

\section{Analisis Sensori}

Analisis sensori dilakukan untuk menentukan produk yang disukai oleh panelis terhadap kerenyahan, warna, dan rasa. Analisis sensori dilakukan dengan pengujian secara organoleptik pada 30 orang panelis.Dari hasil analisis diketahui bahwa perlakuan dengan bleng 1,0\% yang memiliki rangking tertinggi terhadap kerenyahan, warna, dan rasa oleh panelis.

Berdasarkan hasil analisis rasa pada perlakuan penambahan bleng dan kitosan berpengaruh nyata terhadap kerupuk gendar goreng secara sensori. Penambahan kitosan yang terlalu tinggi akan menyebabkan rasa kerupuk gendar goreng menjadi pahit, sehingga panelis tidak suka dengan penambahan kitosan yang berlebihan. Kadar kitosan 0,5 dan 1,0\% dapat diterima panelis terhadap rasa.

\section{SIMPULAN}

Karakteristik kerupuk gendar dengan penambahan kitosan dihasilkan sebagai berikut. Karakteristik fisik meliputi daya kembang kerupuk gendar goreng, yaitu sebesar 28,970-45,487\% dan daya serap minyak sebesar 24,406-40,925\%.Karakteristik kimia kerupuk gendar goreng yaitu kadar air 1,275-1,986\%; kadar abu 0,311-1,775\%; lemak 31,511-33,508\%; protein 4,185-6,250\%; dan karbohidrat 58,546-59,744\%. Analisis sensori kerupuk gendar goreng antara berbahan bleng dengan berbahan kitosan berpengaruh terhadap warna dan berpengaruh nyata pada rasa. Secara sensori kerupuk gendar goreng dengan penambahan kitosan $0,5 \%$ dan 1,0\% dapat diterima oleh panelis untuk karakteristik kerenyahan, warna, dan rasa.

\section{REFERENSI}

Anonim. (1990). Association of Official Agricultural Chemist (AOAC). Official Methods of Analysis. (AOAC). Washington D. C.

Baik, D. O., \& Mittal, S. G. (2003). Kinetics of tofu color changes during deep-fat frying. LebensmittelWissenschaft-und-Technologie, 36, 43-48. 
Mahdar, D. (1990). Pembuatan bleng cair. LaporanKunjungan ke Kabupaten Purwodadi dan Kodya Solo. Balai Besar Penelitian dan Pengembangan Industri Hasil Pertanian.

Mellema, M. (2003). Mechanism and reduction of fat uptake in deep-fat fried foods. Trends in Food Science \& Technology, 14, 364-373.

Moyano, C. P., Rioseco, K. V., \& Gonzalez, A. P. (2002). Kinetics of crust color changes during deepfat frying of impregnated french fries. Journal of Food Engineering, 54, 249-255.

Rossell, B. J. (2001). Factors affecting the quality of frying oils and fats: Improving quality. Cambridge, UK: CRC Press. pp. 115-336.

Setyowati, A. (2010). Penambahan Natrium Tripolifosfat dan CMC (Carboxy Methyl Cellulose) pada pembuatan karak. Jurnal Agri Sains, vol.1 No.1.

Skipnes, D., lesel Van der, P., Ann, V. L., \& Marc, E. H. (2008). Kinetics of heat denaturation of proteins from farmed atlantic cod (Gadus morhua). Journal of Food Engineering, 85, 51-58.

Yohii, Y., \& Arisaka, M. (1994). Relationships between physicochemical properties of nonglutinous rice and degree of expansion of rice cracker. Journal of The Japanese Society for Food Science and Technology-Nippon Shokuhin Kagaku Kogaku Kaishi, 41(11), 747-754.

Zhang, G., \& Hamaker, B. R. (2003). A three component interaction among starch, protein, and free fatty acids revealed by pasting profiles. Journal of Agricultural and Food Chemistry, 51, 27972800. 